\title{
Genetic architecture, epigenetic influence and environment expo- sure in the pathogenesis of Autism
}

\author{
$\mathrm{YU} \mathrm{Li}^{1 \dagger}, \mathrm{WU}$ YiMing ${ }^{1 \dagger} \&$ WU Bai-Lin ${ }^{1,2 *}$ \\ ${ }^{1}$ Children's Hospital of Fudan University, Institutes of Biomedical Science, Shanghai Medical College of Fudan University, Shanghai 200032, China; \\ ${ }^{2}$ Claritas Genomics, Boston Children's Hospital, Harvard Medical School, Boston, MA 02115, USA
}

\begin{abstract}
Autism spectrum disorder (ASD) is a spectral neurodevelopment disorder affecting approximately $1 \%$ of the population. ASD is characterized by impairments in reciprocal social interaction, communication deficits and restricted patterns of behavior. Multiple factors, including genetic/genomic, epigenetic/epigenomic and environmental, are thought to be necessary for autism development. Recent reviews have provided further insight into the genetic/genomic basis of ASD. It has long been suspected that epigenetic mechanisms, including DNA methylation, chromatin structures and long non-coding RNAs may play important roles in the pathology of ASD. In addition to genetic/genomic alterations and epigenetic/epigenomic influences, environmental exposures have been widely accepted as an important role in autism etiology, among which immune dysregulation and gastrointestinal microbiota are two prominent ones.
\end{abstract}

autism spectrum disorder, genetic architecture, genomic disorder, gene mutation, copy number variants, single nucleotide variants, genetic pathways, epigenetic influence, DNA methylation, chromatin remodeling, long non-coding RNAs, environment exposure, immune dysregulation, gastrointestinal microbiota

Citation: Yu L, Wu YM, Wu BL. Genetic architecture, epigenetic influence and environment exposure in the pathogenesis of Autism. Sci China Life Sci, 2015, 58: 958-967, doi: 10.1007/s11427-015-4941-1

Autism spectrum disorder (ASD) is a group of complex neurodevelopmental disorders with large genetic/genomic components. Most recent surveys indicate that the median of ASD prevalence is about 1/160 (62 out of 10000). Among all individuals meeting criteria for autism, essential autism account for approximately $75 \%$ of the cases, and remaining are complex (syndromic) autism. The genetic/genomic alterations identified thus far are highly heterogeneous, including: cytogenetic abnormalities (chromosomal aneuploidy or structural rearrangement, generally refer to chromosome diseases) that can be detected by conventional karyotyping $(<5 \%)$; non-syndromic single gene mutations including rare gene mutation (single nucleotide variant, SNV) and common gene variants (single nucleotide polymorphism, SNP), generally refer to single gene disorders

$\dagger$ Contributed equally to this work

*Corresponding author (email: Bai-Lin.Wu@ childrens.harvard.edu) that can be identified by sequencing $(<5 \%)$, genomic copy number variants $(\mathrm{CNV})$ and structural variation $(\mathrm{SV})$, both generally refer to genomic disorders that can be detected by advanced genomic profiling, such as microarrays and next-generation sequencing $(\sim 10 \%-35 \%)$; syndromic genetic/genomic variants ( 10\%) [1-5]. Figure 1 illustrates estimated detection rates of the ASD patients in each category. None of the identified genes account for more than $1 \%$ of the individuals with ASD, and more than 300-1,000 genes could be associated with ASD.

Genetic factors (genes and genomic regions that bear autism causing mutations or autism risk variants), can only account for about $1 / 3$ of ASD cases. There is still a large portion of heritability unexplainable by current genetic/genomic findings. It is likely that epigenetic influence, environmental factors, and genetic-environment interactions all contribute to the pathogenesis of ASD. 


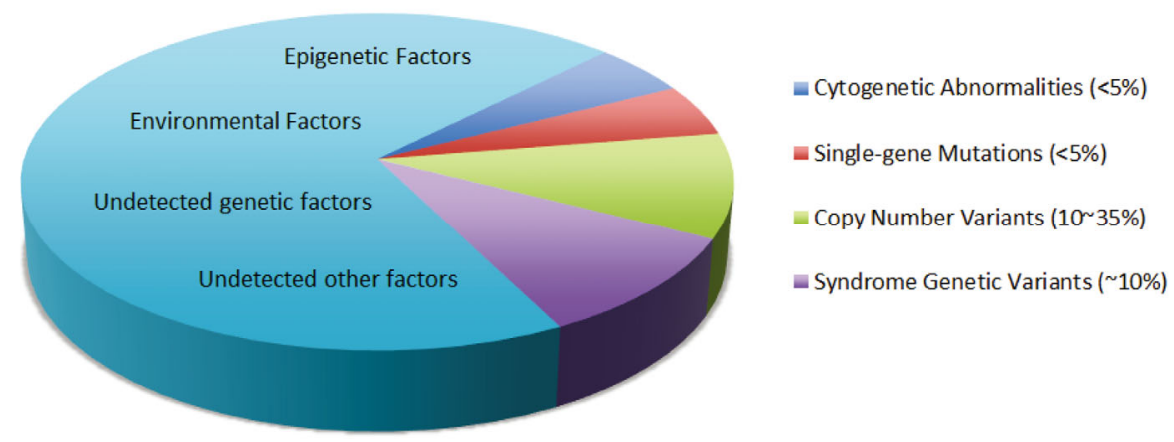

Figure 1 Genetic/genomic, epigenetic/epigenomic, and environmental contributions to autism spectrum disorder (ASD), a group of spectral neurodevelopment disorders. It is currently estimated that single-gene mutations only account for $\sim 5 \%$ of all ASD cases with other genetic abnormalities contributing to additional $5 \%-35 \%$ of all cases.

Over the decades, genetic/genomic research of ASD largely depended on family-based linkage and genome-wide association studies. Neither of these approaches is suitable for the discovery of de novo mutations effectively (i.e. identifying rare SNV, insertion/deletion (indel) and CNV). With the advent of unbiased genomic profiling technology, such as genome-wide microarray analysis and whole-exome or whole-genome sequencing approaches, we can now study at single-nucleotide resolution, the mutational processes that occur in humans from generation to generation and from cell to cell [6].

\section{Rare Copy number variants in ASD}

Numerous researchers have since used a range of microarray-based technology, mainly comparative genomic hybridization (CGH), SNP genotyping (SNP) and CGH/SNP hybrid arrays to investigate the burden of copy-number variants in large cohorts of individuals with ASD, as comprehensively covered in several excellent reviews [1-5] and kept updated by a number of ASD websites (appendix). Several characteristics of CNVs in ASD identified in recent studies are summarized as follows. Roberts et al. used the $105 \mathrm{~K}$ and $180 \mathrm{~K}$ oligonucleotide microarrays to analyze a sample of 65 ASD patients. The most common chromosome involved in the ASD was chromosome 15. In the study, they found that a significantly higher percentage of males were present in the ASD group [7]. Levy et al. also showed that, relative to males, females have greater resistance to autism from genetic causes, which is the gender effect of ASD [8]. Stobbe et al. [9] collected 23 adult patients (range 18-45 years) with confirmed autism. CNVs were demonstrated in 9 of $23(39.1 \%)$ of patients, compared with $18.2 \%$ in published pediatric cases of ASDs [10], which suggested that the adult ASD population is enriched for genomic imbalance and rare CNVs. Girirajan et al. identified recurrent CNVs, including DPPIO, PLCB1, TRPMI, NRXN1, FHIT, and $H Y D I N$, that are enriched in autism by focusing on gene-disruptive events. Their study suggests that the type of
CNV (i.e., duplication or deletion) and extent of DNA changes affect phenotypic manifestation of individuals with autism [11]. Liao et al. revealed that subjects with sex chromosomal aneuploidy are susceptible to neurodevelopmental disorders, including ASD [12]. Girirajan et al. found a significant increase in the number of base pairs of duplication was associated with autism [13].

\section{Rare single-gene mutations in ASD}

With the improvement of next-generation sequencing technologies, it is getting easier for researchers to estimate the contribution of de novo coding-sequence mutations to ASD. Several large-scale sequencing projects including whole exome sequencing (WES) have been made to identify numerous rare single gene mutations and many de novo mutations of high impact could be mapped to highly interconnected protein network [14-19]. Relevant findings from these and other studies are summarized here. Recurrent disruptive mutations in six genes-CHD8, DYRKIA, GRIN2B, TBRI, PTEN, and TBLIXRI-may contribute to $1 \%$ of sporadic ASDs [15]. Except these genes, few de novo mutations recurrently disrupt the same gene. Kong et al. found that de novo point mutations are overwhelmingly paternal in origin (4:1 bias) and positively correlated with paternal age, consistent with the modest increased risk for children of older fathers to develop ASD [17]. Gene- disrupting mutations (nonsense, splice site, and frame shifts) are twice in affected versus unaffected children and have far more impacts on the individual [19]. These studies suggest that protein-truncating de novo SNVs contribute to the risk of ASD for about $10 \%-15 \%$ of probands [20]. The burden of de novo mutations affecting genes expressed in the brain is higher in individuals with ASD as compared with controls [3].

Sequencing analyses reveal the type and rates of small-scale mutations and pinpoints the responsible gene targets more definitively than does copy number or karyotyping. The common theme of variability of phenotype de- 
spite underlying shared genetic susceptibility increasingly suggests that high penetrant mutations associated strictly with ASD, and never with other conditions, may be extremely rare or nonexistent. However, the contribution of de novo events are underestimated for following reasons. First, in current studies, stringent criteria are used to eliminate false positives and many true positives fail to be detected as a consequence. Second, it would be likely to miss even a $5 \%$ differential from de novo missense mutations, given the high background rate of neutral missense mutations. Third, due to exome capture limitations or errors in the reference genome, the coverage of genomic regions is incomplete. Fourth, mutation calls are made from only coding regions, and therefore, noncoding regions are missed that might affect RNA expression or processing [19-21].

\section{Candidate genes in ASD}

Because of the significant overlap between the genetic etiology of ASD and other neuropsychiatric and neurodevelopmental disorders, more and more candidate genes are found in recent studies. At the same time, given the low rate of recurrence among genes with de novo mutations, estimates of overall locus heterogeneity for ASD have yielded between 300 and 1000 genes that could confer increased ASD risk when subjected to de novo mutations [20].

In recent studies, Lee et al. identified $K C N D 2$ as the causal gene for epilepsy. Interaction of $K C N D 2$ with other genes implicated in autism, and the role of $K C N D 2$ in synaptic plasticity provides suggestive evidence of an etiological role in autism [22]. Matsunami et al. used haplotype sharing and identified 39 variants in 36 genes that may confer a genetic risk of developing autism [23]. Cukier et al. performed whole exome sequencing on 100 ASD individuals from 40 families with multiple distantly related affected individuals. They identified numerous potentially damaging, ASD-associated risk variants in genes previously unrelated to autism (SLIT3, CLCN2, PRICKLE1, AP4M1, WDR60, $O F C C 1)$. Additional alterations were found in previously reported autism candidate genes (CEP290, CSMD1, FAT1, and $S T X B P 5)$. In this study, they found that variants occurred in ASD candidate genes were 1.65 times more frequently than in random genes captured by exome sequencing [24]. Shi et al. identified 59 candidate variants that may increase susceptibility to autism. Manual examination of this list identified $A N K 3$ as the most likely candidate gene [25]. Xia et al. suggested TRIM33 and NRAS-CSDE1 as candidate genes for autism, and may provide a novel insight into the etiology of autism [26].

Given that autism is a complex neurodevelopmental and neuropsychiatric disease, multiple contributing variants in the family may increase susceptibility. It is likely that studies focusing on de novo or inherited mutations can complement each other, and reveal a more comprehensive picture of susceptibility to ASDs.

\section{Common genetic variants in ASD}

The absence of classical Mendelian inheritance has led to the proposal that autism is polygenic involving many common variants, each with a small effect. A number of linkage studies and genome-wide association studies (GWAS) have been performed. Nijmeijer et al. studied 261 ADHD probands and 354 of their siblings to assess quantitative trait loci associated with ASD and identified a genome-wide significant locus on chromosome 7q11 [27]. Xia et al. used two Chinese cohorts for gene discovery $(n=2150)$ and three data sets of European ancestry populations for replication analysis of top association signals. Meta-analysis identified three single-nucleotide polymorphisms and related haplotypes; all were mapped to a previously reported linkage region (1p13.2) with autism [26]. Kovac et al. identified two single nucleotide polymorphisms (SNPs). Both are located in the noncoding regulatory regions of the superoxide dismutase 1 (SOD1) gene, with a minor allele frequency in healthy population at approximately $5 \%$. This suggests the importance of noncoding genetic variants in the regulation of gene expression [28]. Weiss LA et al. performed a linkage and association mapping study using half a million genome-wide single nucleotide polymorphisms (SNPs) in a common set of 1,031 multiplex autism families (1,553 affected offspring). They identified regions of suggestive and significant linkage on chromosomes 6q27 and 20p13, respectively [29].

Common variants such as SNPs contribute to ASD susceptibility, although individually they are associated with very small effects and are widely distributed across the genome. In the future, comprehensive assessment of the genetic background of each individual might be of great importance in better predicting clinical outcomes.

\section{Genetic pathways associated with ASD}

Several pathway analyses have been performed using either genetic/genomic or transcriptomic data to gain insight into the biological functions associated with ASD. Recent studies have led to a convergence on three functional pathways among ASD and ID (intellectual disability): (i) synaptic function; (ii) Wnt signaling during development; and (iii) chromatin remodeling [20].

$\mathrm{CNV}$ studies have provided strong evidence for the involvement of important gene networks in ASD. In an early whole-genome CNV study in 2009, Glessner et al. presented the results on a cohort of 859 ASD cases and 1,409 healthy children of European ancestry [30]. In 2010, Pinto et al. compared 996 ASD individuals of European ancestry to 1,287 matched controls to screen for rare CNVs [31]. Among the de novo and inherited CNVs, many novel ASD genes such as SHANK2, SYNGAP1, DLGAP2 and the 
X-linked DDX53-PTCHD1 locus were implicated [31]. Although these variants may be individually rare, they target genes involved in synaptic formation, neuronal cell-adhesion or ubiquitin degradation and GTPase/Ras signalling, indicating that these important gene networks expressed within the central nervous system may contribute to the genetic susceptibility of ASD. Chow et al. provided evidence for dysregulation of pathways governing cell number, cortical patterning, and differentiation in young autistic prefrontal cortex. In contrast, adult autistic prefrontal cortex showed dysregulation of signaling and repair pathways [32]. Gilman et al. developed a method for network-based analysis of genetic associations (NETBAG) to identify gene networks affected by rare de novo CNVs in ASD. Their data uncovered networks critical in synapse development, axon targeting, and neuron motility [14].

Using gene expression, protein-protein interactions, and CNV pathway analysis, a few reports have highlighted the role of synapse formation and maintenance and supported a role for these interconnected pathways in neuronal stem cell fate determination, differentiation and synaptic formation in ASD cases and animal models [14,16,33,34]. The Wnt signaling pathway plays a crucial role in diverse processes associated with formation of neural circuits [14].

These pathways provide potential drug targets for ASD. Clinical trials are ongoing to determine whether targeting them could improve the symptoms of individuals affected by ASD.

\section{Epigenetic influences in the pathogenesis of ASD}

Hundreds of ASD-associated genes have been identified. However, a large portion of heritability remains unexplainable by genetic findings, including those monozygotic (MZ) twins who are discordant for ASD. Therefore, it has long been suspected that epigenetic influences may contribute to the pathogenesis of ASD. Epigenetic/epigenomic mechanisms, including DNA methylation, chromatin remodeling by histone modifications (methylation, acetylation, phosphorylation, etc.) or ATP-dependent SWI/SNF complexes, may impacts on the quantity and quality of gene products at different levels $[35,36]$. Efforts have been made to elucidate the roles of these factors in ASD.

\subsection{Altered DNA methylation in ASD}

Altered DNA methylation has been found during brain development in several neuropsychiatric diseases [37-40]. $M E C P 2$, a well-known epigenetic regulation gene, has been reported to be truncated or aberrantly methylated in Rett syndrome and autism [41,42]. Besides, ASD-associated genes, including OXTR [43], SHANK3 [44], FMR1 [45], have also been found to have hypermethylation status in their promoters or upstream regions among ASD patients. These findings support that aberrant DNA methylation may have an important role in ASD pathogenesis.

To further examine the contribution of DNA methylation to ASD, Nguyen et al. conducted a large-scale methylation profiling study by using lymphoblastoid cell lines from MZ twins discordant for autism and unaffected siblings. They identified over 200 differentially methylated $\mathrm{CpG}$ islands, with an enrichment of "nervous system development and function" in gene ontology analysis (GO) [46]. In 2014, two important studies further addressed role of DNA methylation in ASD. Ladd-Acosta et al. performed a genome-wide screen of DNA methylation in post-mortem brain tissue from 19 autism cases and 21 unrelated controls [47]. They identified 4 genome-wide significant differentially methylated regions (DMRs) and replicated 3 of them, although no known ASD-associated genes showed abnormal methylation in this study. Wong et al. carried out genome-wide analyses of DNA methylation in 50 monozygotic twin pairs discordant for ASD [48]. In addition, DNA methylation was significantly correlated with the Childhood Autism Symptom Test (CAST) scores. These two genome-wide DNA methylation findings in ASD have revealed numerous hypermethylated loci with candidate genes, but few of them have overlap with known ASD-associated genes identified from sequencing or CNV studies. This raised the question of the precise role of DNA methylation in ASD pathogenesis. Future studies are necessary for validate previous findings in larger sample cohorts and examine the effect of these newly identified genes in ASD pathogenesis.

\subsection{Chromatin remodeling genes in ASD}

Chromatin remodeling genes contribute to the fine-tuning of DNA condensing status and to the regulation of open conformation so as to allow the accessibility of transcription factors. Post-translational modifications, such as methylation, acetylation and phosphorylation of histone subunits, can alter the chromatin structure or conformation. Chromatin remodeling proteins are essential for neural development and dynamic activity. Alterations of these regulators can lead to neurological lesions [49-52].

Previous CNV and exome studies have revealed a number of chromatin remodeling genes harboring disruptive mutations in ASD patients. KDM5C encodes a histone demethylase. KDM5C mutations have been associated with $\mathrm{X}$-linked mental retardation and ASD [53,54]. ARIDIB, a component of SWI/SNF chromatin remodeling complex is important for speech development. ARIDIB truncation mutations have been identified in ASD patients [55]. CHD8, an ATP-dependent helicase in Wnt signaling pathway, have recently been recognized as a frequently mutated genes in ASD [15,16,56,57]. Interestingly, the expression of $S C N 2 A$, another ASD- associated gene which also shows a high occurrence in ASD exome findings [18,58], is under the regu- 
lation of $K D M 5 C$ [59]. Recently, an integrative analysis of several published exome studies in ASD showed an over-representation of changes in chromatin regulatory genes in ASD cases as compared with unaffected siblings [60]. These results suggest an important role of chromatin remodeling genes in ASD pathogenesis.

\section{Long non-coding RNAs (IncRNAs) in ASD}

Long non-coding RNAs can modulate chromatin structure and conformation by their association with regulatory proteins [61,62]. In a lncRNAs transcriptome study of post-mortem brain tissue of ASD patients [63], 222 differentially expressed lncRNAs between ASD and controls were identified, with an enrichment of genes associated with neuronal migration. It should be cautioned that the sample size was small with only 2 patient samples with 2 controls in this study.

\section{Environmental factors in the pathogenesis of ASD}

Environmental exposures have been proposed to contribute to ASD pathogenesis, among which immune responses and gastrointestinal microbiota are the two prominent ones. Accumulating evidence supports that these environmental factors may modulate known ASD candidate genes.

\subsection{Immune dysregulation in ASD}

Immune proteins play crucial roles in brain development [64]. The MHC-I (major histocompatibility complex class I) proteins, a key player in adaptive immunity, is enriched in synaptic fractions and the deficiency of which can result in enlarged neural projections [65]. MHC-I can negatively regulate synapse density during the formation of cortical connections via signaling pathways which require MEF2, an ASD candidate gene [66,67]. C1q and C3 (complement proteins of the innate immune system), and TNF- $\alpha$ are all expressed in the developing brain and play vital roles in synapse refinement $[68,69]$. Although there is no definitive conclusion that immune dysfunction can cause neurodevelopmental disorders such as ASD, maternal immune activation and increased levels of pro-inflammatory cytokines in the fetal brain may affect fetal brain development if the time of exposure coincides with critical processes in neurodevelopment, such as dendritic pruning and synaptic scaling $[68,70]$.

Maternal immune activation during the first or second trimesters has been recognized as a potential risk factor for ASD in the offsprings [71,72]. Anti-fetal antibodies can pass the blood-brain barrier which is not fully developed during the prenatal period [73]. Braunschweig et al. identi- fied that anti-fetal brain antibodies, $\operatorname{IgG}$, were found in $\sim 11.5 \%$ of mothers of children with ASD, but not in mothers of children of typical development and mothers of children with development delay [74]. Injections of IgG collected from mothers of children with ASD into pregnant rhesus monkeys during the first and second trimesters led to altered brain volume and social behavior development in the offspring [75]. Analyses of post-mortem brain tissues of ASD patients with ages ranging from children to adults have revealed microglia activation and increased cytokines including TNF- $\alpha$ and IL-6, suggesting ongoing neuroinflammation in the brains of ASD patients [76,77]. These findings indicate that immune responses may impact on ASD pathogenesis.

Microglial cells, the "immune cells in brain", have various functions in the central nervous system. They can secrete TNF- $\alpha$ and IL- 6 under inflammatory conditions, provide growth factors in early synaptogenesis, eliminate redundant synapses, and modulate synaptic transmission [78,79]. Morgan et al. found microglial cells were activated in approximately $40 \%$ of their autism samples together with an increase in the average microglial somal volume in white mater [77]. Suzuki et al. further investigated the patterns of distribution of microglial activation in the brain of ASD patients by PET imaging, and found increased microglial activation in the dorsolateral prefrontal cortex in ASD patients although the microglial distribution patterns were similar [80].

Immune response is not specific for autism and is especially critical in crucial fetal development stage, which suggests genetic factors may act as a modifier in its impact on brain development. Since TSC-mTOR signaling is a known modulator of immune response, Ehninger et al. investigated the effect of the cooperation of TSC2 haploinsufficiency with gestational immune activation and found it can perturb social behavior in adult mice [81]. Moreover, transcriptome analyses have provided convergent evidence supporting the role of immune genes in ASD. Voineagu et al. examined gene expression profiling of prefrontal and temporal cortex of post-mortem brain tissues of ASD patients from different age groups and through a network-based approach identified two central modules of co-expressed genes which were dysregulated in ASD patients. One of these modules was upregulated and enriched for genes involved in immune and inflammatory responses [34]. Further genetic and functional studies will improve our understanding of the involvement of immune responses in ASD.

\subsection{Gastrointestinal microbiota in ASD}

Immune responses may also cause gastrointestinal (GI) problems through inflammation as well [82]. Various studies have reported the prevalence of GI problems, one of common comorbid conditions of ASD [83,84]. Accumulat- 
ed findings lead to the hypothesis of gut-brain axis, which suggests that gut microbiota can alter brain activity through endocrinal, metabolic or immunological mechanisms, and can possibly induce the pathogenesis of ASD [85-88].

Gut microbiota may influence the development of social behavior. It was reported that germ-free (GF) mice showed significant social behavior impairments, particular in males, and that microbial interventions could ameliorate the social avoidance in GF mice without affecting social cognition impairments [89]. In 2013, Hsiao et al. did a remarkable study in which they found mice offspring affected by maternal immune activation, which display defects in intestinal integrity and ASD-like behavioral abnormalities, can have its intestinal and behavioral symptoms both ameliorated after receiving the treatment after weaning with the gut bacterium Bacteroides fragilis [90]. This is the first report that altered behavioral abnormalities can be alleviated by restoration of GI microbiota, which strongly supports the gut-brain axis hypothesis.

So far most studies on the relationship between GI problems and ASD are mainly conducted in rodent or primate models generated by maternal immune activation, while studies using human samples have no reports of the diagnosed genetic basis, this leads to the question of whether GI problems only exist in subgroups of offspring of maternal immune activation and whether probiotic treatment for ASD children with single-gene mutation or CNV can also improve their conditions. Besides, it is also interesting that whether probiotic treatment at different postnatal stage may have impacts of different levels on brain development of ASD children, since currently no studies in this sub-area involves the critical period of children development. These warrant deeper collaboration between medical geneticists and clinician, and further study of the mechanism through which gut microbiota can alter the activity of brain.

\section{Valuable ASD websites and resources}

\subsection{AutDB}

AutDB (http://autism.mindspec.org/autdb/Welcome.do) (Appendix 1), cataloguing a richly annotated gene list for autism and maintained by MindSpec, has the manually curated information of different types of research data from association studies, chromosomal structural variation studies, studies of genetic disorders with single-gene mutations, and animal model studies, etc. Experts in different specialized fields are hired to extract information from published papers on autism to keep AutDB with latest up-to-date information. Listed genes are categorized as "Genetic Association", "Syndromic", "Functional" and "Rare single gene variant". In the section of each gene, a basic summary and corresponding references are provided alongside with the information of both rare and common sequence variants, animal model existence, and protein interactions. In "Animal Model" part, construct details and phenotypic profile is available, while in "PIN" (protein interaction) part, all known linked genes are presented as a colored diagram and a detailed table as well. AutDB also contains a section of listed information of CNV research in autism and implements a helpful search query engine based on researchers' interests.

\subsection{SFARI gene}

Simons Foundation received the licensed AutDB from MindSpec in 2008, and the licensed AutDB is thus named as SFARI Gene (https://gene.sfari.org/autdb/Welcome.do) (Appendix 2). SFARI adds an additional interactive module which enables research community to contribute their annotations to genes. This module implements a process for gene scoring and classifies genes based on their relevance to autism into six categories of confidence level from "Highly Confidence" to "Not Supported", and an another category of "Syndromic". This module encourages the participation of community researchers, and the gene score is quite intuitive for further consideration of functional studies or bioinformatic analysis. Besides this major difference, SFARI also adds other additional information. For example, in "Animal Models" section, a "Rescue Models" information is provided which mainly contains pharmaceutical intervention which helps to alleviate autism phenotypes, thus helping researchers further examine the function of these genes in the context of development.

\subsection{Autism chromosome rearrangement database}

Autism chromosome rearrangement database (http://projects. tcag.ca/autism/) (Appendix 3), hosted by The Centre for Applied Genomics (TCAG) of the Hospital for Sick Children, Toronto, is a database listing curated structural variants finding in autism spectrum disorder. This database contains not only extracted information from published literature but also in-house experimental data. It implements three types of information retrieval: the "Cytogenetic Data" centralized, the "Microarray Data" centralized, and the "Keyword Search" method which allows user to search for matched data of clone name, accession number, cytoband or gene symbol. The description information of individuals is provided but not in the form of tabularized data as in the case of AutDB and SFARI.

\subsection{DECIPHER}

DECIPHER (http://decipher.sanger.ac.uk/) (Appendix 4) (Database of Chromosomal Imbalance and Phenotype in Humans Using Ensemble Resources), maintained by Welcome Trust Sanger Institute, is an interactive database and has a suite of tools for researchers to interpreter chromoso- 
mal structural variations. It contains chromosomal aberrations upload by more than 200 centers comprising more than 10,000 cases which are found not only in autism but in other developmental disorders as well. Users can view related information based on syndromes or karyotypes. The interface shows recorded copy number changes in color ("Loss" in red, and "Gain" in blue), while genes of recognized clinical importance are highlighted. The pathogenic contribution of the variants can be further viewed either in UCSC genome browser or Ensemble browser in which the genomic and phenotypic information of each patient harboring the variants can be retrieved. The graphical presentation greatly enhances to assess clinical relevance of copy number change in users' data intuitively.

\subsection{AutismKB}

AutismKB (http://autismkb.cbi.pku.edu.cn/index.php) (Appendix 5), hosted by Peking University, is an evidence-based knowledgebase for ASD. It currently contains 3075 genes, 4964 copy number variations and 158 linkage regions associated with ASD based on the met of following criteria: genome-wide association studies, genome-wide CNV studies, linkage analysis, low-scale genetic association studies, expression profiling and other low-scale gene studies, and these information can be browsed in the section of corresponding research method. Although the total numbers apparently are over-estimated and the criteria are quite loose, this database provides a "high-confidence" list of 99 syndromic autism related genes and 109 non-syndromic autism associated genes based on its scoring and ranking system. AutismKB also enables users to view the result of gene set enrichment analyses by enriched GO, enriched pathway or enriched GO map, providing information in the context of gene ontology.

This work was supported by grants from the National Basic Research Program of China (973 Program, 2010CB529601, 2013CB945404).

\section{Disclosure Statement}

The authors are not aware of any affiliations, memberships, funding, or financial holdings that might be perceived as affecting the objectivity of this review.

1 Rosti RO, Sadek AA, Vaux KK, Gleeson JG. The genetic landscape of autism spectrum disorders. Dev Med Child Neurol, 2014: 56: 12-18

2 Devlin B, Scherer SW. Genetic architecture in autism spectrum disorder. Curr Opin Genet Dev, 2012, 22: 229-237

3 Huguet G, Ey E, Bourgeron T. The genetic landscapes of autism spectrum disorders. Annu Rev Genom Hum G, 2013, 14: 191-213

4 Shishido E, Aleksic B, Ozaki N. Copy-number variation in the pathogenesis of autism spectrum disorder. Psychiat Clin Neuros, 2014, 68: 85-95

5 Betancur C. Etiological heterogeneity in autism spectrum disorders: more than 100 genetic and genomic disorders and still counting.
Brain Res, 2011, 1380: 42-77

6 Veltman JA, Brunner HG. De novo mutations in human genetic disease. Nat Rev Genet, 2012, 13: 565-575

7 Roberts JL, Hovanes K, Dasouki M, Manzardo AM, Butler MG. Chromosomal microarray analysis of consecutive individuals with autism spectrum disorders or learning disability presenting for genetic services. Gene, 2014, 535: 70-78

8 Levy D, Ronemus M, Yamrom B, Lee YH, Leotta A, Kendall J. Rare de novo and transmitted copy-number variation in autistic spectrum disorders. Neuron, 2011, 70: 886-897

9 Stobbe G, Liu YJ, Wu R, Hudgings LH, Thompson O, Hisama FM. Diagnostic yield of array comparative genomic hybridization in adults with autism spectrum disorders. Genet Med, 2014, 16: 70-77

10 Shen, Y, Dies, KA, Holm IA, Bridgemohan C, Sobeih MM, Caronna EB, Miller KJ, Frazier JA, Silverstein I, Picker J, Weissman L, Raffalli P, Jeste S, Demmer LA, Peters HK, Brewster SJ, Kowalczyk SJ, Rosen-Sheidley B, McGowan C, Duda III AW, Lincoln SA, Lowe KR, Schonwald A, Robbins M, Hisama F, Wolff R, Becker R, Nasir R, Urion DK, Milunsky JM, Rappaport L, Gusella JF, Walsh CA, Wu BL, Miller DT on behalf of the Autism Consortium Clinical Genetics/DNA Diagnostics Collaboration. Clinical genetic testing for patients with autism spectrum disorders. Pediatrics, 2010, 125: 727-735

11 Girirajan S, Dennis Megan Y, Baker C, Malig M, Coe Bradley P, Campbell Catarina D. Refinement and discovery of new hotspots of copy-number variation associated with autism spectrum disorder. Am J Hum Genet, 2013, 92: 221-237

12 Liao HM, Gau SS, Tsai WC, Fang JS, Su YC, Chou MC, Liu SK, Chou WJ, Wu YY, Chen CH. Chromosomal abnormalities in patients with autism spectrum disorders from Taiwan. Am J Med Genet B, 2013, 162B: 734-741

13 Girirajan S, Johnson RL, Tassone F, Balciuniene J, Katiyar N, Fox K, Baker C, Srikanth A, Yeoh KH, Khoo SJ, Nauth TB, Hansen R, Ritchie M, Hertz-Picciotto I, Eichler EE, Pessah IN, Selleck SB. Global increases in both common and rare copy number load associated with autism. Hum Mol Genet, 2013, 22: 2870-2880

14 Gilman SR, Iossifov I, Levy D, Ronemus M, Wigler M, Vitkup D. Rare de novo variants associated with autism implicate a large functional network of genes involved in formation and function of synapses. Neuron, 2011, 70: 898-907

15 O'Roak BJ, Vives L, Fu W, Egertson JD, Stanaway IB, Phelps IG, Carvill G, Kumar A, Lee C, Ankenman K, Munson J, Hiatt JB, Turner EH, Levy R, O'Day DR, Krumm N, Coe BP, Martin BK, Borenstein E, Nickerson DA, Mefford HC, Doherty D, Akey JM, Bernier R, Eichler EE, Shendure J. Multiplex targeted sequencing identifies recurrently mutated genes in autism spectrum disorders. Science, 2012, 338: 1619-1622

16 O'Roak BJ, Vives L, Girirajan S, Karakoc E, Krumm N, Coe BP, Levy R, Ko A, Lee C, Smith JD, Turner EH, Stanaway IB, Vernot B, Malig M, Baker C, Reilly B, Akey JM, Borenstein E, Rieder MJ, Nickerson DA, Bernier R, Shendure J, Eichler EE. Sporadic autism exomes reveal a highly interconnected protein network of de novo mutations. Nature, 2012, 485: 246-250

17 Kong A, Frigge ML, Masson G, Besenbacher S, Sulem P, Magnusson G, Gudjonsson SA, Sigurdsson A, Jonasdottir A, Jonasdottir A, Wong WS, Sigurdsson G, Walters GB, Steinberg S, Helgason H, Thorleifsson G, Gudbjartsson DF, Helgason A, Magnusson OT, Thorsteinsdottir U, Stefansson K. Rate of de novo mutations and the importance of father's age to disease risk. Nature, 2012, 488: 471-475

18 Sanders SJ, Murtha MT, Gupta AR, Murdoch JD, Raubeson MJ, Willsey AJ, Ercan-Sencicek AG, DiLullo NM, Parikshak NN, Stein JL, Walker MF, Ober GT, Teran NA, Song Y, El-Fishawy P, Murtha RC, Choi M, Overton JD, Bjornson RD, Carriero NJ, Meyer KA, Bilguvar K, Mane SM, Sestan N, Lifton RP, Günel M, Roeder K, Geschwind DH, Devlin B, State MW. De novo mutations revealed by whole-exome sequencing are strongly associated with autism. Nature, 2012, 485: 237-241

19 Iossifov I, Ronemus M, Levy D, Wang Z, Hakker I, Rosenbaum J, Yamrom B, Lee YH, Narzisi G, Leotta A, Kendall J, Grabowska E, 
Ma B, Marks S, Rodgers L, Stepansky A, Troge J, Andrews P, Bekritsky M, Pradhan K, Ghiban E, Kramer M, Parla J, Demeter R, Fulton LL, Fulton RS, Magrini VJ, Ye K, Darnell JC, Darnell RB, Mardis ER, Wilson RK, Schatz MC, McCombie WR, Wigler M . De novo gene disruptions in children on the autistic spectrum. Neuron, 2012, 74: 285-299

20 Krumm N, O'Roak BJ, Shendure J, Eichler EE. A de novo convergence of autism genetics and molecular neuroscience. Trends Neurosci, 2014, 37: 95-105

21 Yu TW, Chahrour MH, Coulter ME, Jiralerspong S, Okamura-Ikeda K, Ataman B, Schmitz-Abe K,Harmin DA,Adli M, Malik AN, D'Gama AM, Lim ET, Sanders SJ, Mochida GH, Partlow JN, Sunu CM, Felie JM, Rodriguez J, Nasir RH, Ware J, Joseph RM, Hill RS, Kwan BY, Al-Saffar M, Mukaddes NM, Hashmi A, Balkhy S, Gascon GG, Hisama FM, LeClair E, Poduri A, Oner O, Al-Saad S, Al-Awadi SA, Bastaki L, Ben-Omran T, Teebi AS, Al-Gazali L, Eapen V, Stevens CR, Rappaport L, Gabriel SB, Markianos K, State MW, Greenberg ME, Taniguchi H, Braverman NE, Morrow EM, Walsh CA. Using whole-exome sequencing to identify inherited causes of autism. Neuron, 2013, 77: 259-273

22 Lee H, Lin MC, Kornblum HI, Papazian DM, Nelson SF. Exome sequencing identifies de novo gain of function missense mutation in $K C N D 2$ in identical twins with autism and seizures that slows potassium channel inactivation. Hum Mol Genetics, 2014, 5: 5

23 Matsunami N, Hensel CH, Baird L, Stevens J, Otterud B, Leppert T, Varvil T, Hadley D, Glessner JT, Pellegrino R, Kim C, Thomas K, Wang F, Otieno FG, Ho K, Christensen GB, Li D, Prekeris R, Lambert CG, Hakonarson H, Leppert MF. Identification of rare DNA sequence variants in high-risk autism families and their prevalence in a large case/control population. Mol Autism, 2014, 5: 5

24 Cukier HN, Dueker ND, Slifer SH, Lee JM, Whitehead PL, Lalanne E, Leyva N, Konidari I, Gentry RC, Hulme WF, Booven DV, Mayo V, Hofmann NK, Schmidt MA, Martin ER, Haines JL, Cuccaro ML, Gilbert JR, Pericak-Vance MA. Exome sequencing of extended families with autism reveals genes shared across neurodevelopmental and neuropsychiatric disorders. Mol Autism, 2014, 5: 1

25 Shi LL, Zhang X, Golhar R, Otieno FG, He MZ, Hou CP, Kim C, Keating B, Lyon GJ, Wang K, Hakonarson H. Whole-genome sequencing in an autism multiplex family. Mol Autism, 2013, 4: 8

26 Xia K, Guo H, Hu Z, Xun G, Zuo L, Peng Y, Wang K, He Y, Xiong Z, Sun L, Pan Q, Long Z, Zou X, Li X, Li W, Xu X, Lu L, Liu Y, Hu Y, Tian D, Long L, Ou J, Liu Y, Li X, Zhang L, Pan Y, Chen J, Peng H, Liu Q, Luo X, Su W, Wu L, Liang D, Dai H, Yan X, Feng Y, Tang B, Li J, Miedzybrodzka Z, Xia J, Zhang Z, Luo X, Zhang X, St Clair D, Zhao J, Zhang F. Common genetic variants on 1p13.2 associate with risk of autism. Mol Psychiatry, 2014, 19: 1212-1219

27 Nijmeijer JS, Arias-Vásquez A, Rommelse NNJ, Altink ME, Buschgens CJM, Fliers EA, Franke B, Minderaa RB, Sergeant JA, Buitelaar JK, Hoekstra PJ, Hartman CA. Quantitative linkage for autism spectrum disorders symptoms in attention-deficit/ hyperactivity disorder: significant locus on chromosome 7q11. J Autism Dev Disord. 2014, 44: 1671-1680

28 Kovač J, Macedoni Lukšič M, Trebušak Podkrajšek K, Klančar G, Battelino T. Rare single nucleotide polymorphisms in the regulatory regions of the superoxide dismutase genes in autism spectrum disorder. Autism Res, 2014, 7: 138-144

29 Weiss LA, Arking DE, Gene Discovery Project of Johns H, the Autism C, Daly MJ, Chakravarti A. A genome-wide linkage and association scan reveals novel loci for autism. Nature, 2009, 461: 802-808

30 Glessner JT, Wang K, Cai G, Korvatska O, Kim CE, Wood S, Estes A, Brune CW, Bradfield JP, Imielinski M, Frackelton EC, Reichert J, Crawford EL, Munson J, Sleiman PM, Chiavacci R, Annaiah K, Thomas K, Hou C, Glaberson W, Flory J, Otieno F, Garris M, Soorya L, Klei L, Piven J, Meyer KJ, Anagnostou E, Sakurai T, Game RM, Rudd DS, Zurawiecki D, McDougle CJ, Davis LK, Miller J, Posey DJ, Michaels S, Kolevzon A, Silverman JM, Bernier R, Levy SE, Schultz RT, Dawson G, Owley T, McMahon WM, Wassink TH, Sweeney JA, Nurnberger JI, Coon H, Sutcliffe JS, Minshew NJ,
Grant SF, Bucan M, Cook EH, Buxbaum JD, Devlin B, Schellenberg GD, Hakonarson H. Autism genome-wide copy number variation reveals ubiquitin and neuronal genes. Nature, 2009, 459: 569-573

31 Pinto D, Pagnamenta AT, Klei L, Anney R, Merico D, Regan R, Conroy J, Magalhaes TR, Correia C, Abrahams BS, Almeida J, Bacchelli E, Bader GD, Bailey AJ, Baird G, Battaglia A, Berney T, Bolshakova N, Bölte S, Bolton PF, Bourgeron T, Brennan S, Brian J, Bryson SE, Carson AR, Casallo G, Casey J, Chung BH, Cochrane L, Corsello C, Crawford EL, Crossett A, Cytrynbaum C, Dawson G, de Jonge M, Delorme R, Drmic I, Duketis E, Duque F, Estes A, Farrar P, Fernandez BA, Folstein SE, Fombonne E, Freitag CM, Gilbert J, Gillberg C, Glessner JT, Goldberg J, Green A, Green J, Guter SJ, Hakonarson H, Heron EA, Hill M, Holt R, Howe JL, Hughes G, Hus V, Igliozzi R, Kim C, Klauck SM, Kolevzon A, Korvatska O, Kustanovich V, Lajonchere CM, Lamb JA, Laskawiec M, Leboyer M, Le Couteur A, Leventhal BL, Lionel AC, Liu XQ, Lord C, Lotspeich L, Lund SC, Maestrini E, Mahoney W, Mantoulan C, Marshall CR, McConachie H, McDougle CJ, McGrath J, McMahon WM, Merikangas A, Migita O, Minshew NJ, Mirza GK, Munson J, Nelson SF, Noakes C, Noor A, Nygren G, Oliveira G, Papanikolaou K, Parr JR, Parrini B, Paton T, Pickles A, Pilorge M, Piven J, Ponting CP, Posey DJ, Poustka A, Poustka F, Prasad A, Ragoussis J, Renshaw K, Rickaby J, Roberts W, Roeder K, Roge B, Rutter ML, Bierut LJ, Rice JP, Salt J, Sansom K, Sato D, Segurado R, Sequeira AF, Senman L, Shah N, Sheffield VC, Soorya L, Sousa I, Stein O, Sykes N, Stoppioni V, Strawbridge C, Tancredi R, Tansey K, Thiruvahindrapduram B, Thompson AP, Thomson S, Tryfon A, Tsiantis J, Van Engeland H, Vincent JB, Volkmar F, Wallace S, Wang K, Wang Z, Wassink TH, Webber C, Weksberg R, Wing K, Wittemeyer K, Wood S, Wu J, Yaspan BL, Zurawiecki D, Zwaigenbaum L, Buxbaum JD, Cantor RM, Cook EH, Coon H, Cuccaro ML, Devlin B, Ennis S, Gallagher L, Geschwind DH, Gill M, Haines JL, Hallmayer J, Miller J, Monaco AP, Nurnberger JI Jr, Paterson AD, Pericak-Vance MA, Schellenberg GD, Szatmari P, Vicente AM, Vieland VJ, Wijsman EM, Scherer SW, Sutcliffe JS, Betancur C. Functional impact of global rare copy number variation in autism spectrum disorders. Nature, 2010, 466: 368-372

32 Chow ML, Pramparo T, Winn ME, Barnes CC, Li HR, Weiss L, Fan JB, Murray S, April C, Belinson H, Fu XD, Wynshaw-Boris A, Schork NJ, Courchesne E. Age-dependent brain gene expression and copy number anomalies in autism suggest distinct pathological processes at young versus mature ages. PLoS Genet, 2012, 8: e1002592

33 Sakai Y, Shaw CA, Dawson BC, Dugas DV, Al-Mohtaseb Z, Hill DE, Zoghbi HY. Protein interactome reveals converging molecular pathways among autism disorders. Sci Trans1 Med, 2011, 3: 86ra49

34 Voineagu I, Wang X, Johnston P, Lowe JK, Tian Y, Horvath S, Mill J, Cantor RM, Blencowe BJ, Geschwind DH. Transcriptomic analysis of autistic brain reveals convergent molecular pathology. Nature, 2011, 474: 380-384

35 Sweatt JD. The emerging field of neuroepigenetics. Neuron, 2013, 80: 624-632

36 LaSalle JM, Powell WT, Yasui DH. Epigenetic layers and players underlying neurodevelopment. Trends Neurosci, 2013, 36: 460-470

37 Lalande M, Calciano MA. Molecular epigenetics of Angelman syndrome. Cell Mol Life Sci, 2007, 64: 947-960

38 Graff J, Mansuy IM. Epigenetic codes in cognition and behaviour. Behav Brain Res, 2008, 192: 70-87

39 Badcock C. The imprinted brain: how genes set the balance between autism and psychosis. Epigenomics, 2011, 3: 345-359

40 Houston I, Peter CJ, Mitchell A, Straubhaar J, Rogaev E, Akbarian S. Epigenetics in the human brain. Neuropsychopharmacology, 2013, 38: 183-197

41 Nagarajan RP, Patzel KA, Martin M, Yasui DH, Swanberg SE, Hertz-Picciotto I, Hansen RL, Van de Water J, Pessah IN, Jiang R, Robinson WP, LaSalle JM. MECP2 promoter methylation and X chromosome inactivation in autism. Autism Res, 2008, 1: 169-178

42 LaSalle JM, Yasui DH. Evolving role of $M e C P 2$ in Rett syndrome and autism. Epigenomics, 2009, 1: 119-130 
43 Harony-Nicolas H, Mamrut S, Brodsky L, Shahar-Gold H, Barki-Harrington L, Wagner S. Brain region-specific methylation in the promoter of the murine oxytocin receptor gene is involved in its expression regulation. Psychoneuroendocrinology, 2014, 39: 121-131

44 Zhu L, Wang X, Li XL, Towers A, Cao X, Wang P, Bowman R, Yang H, Goldstein J, Li YJ, Jiang YH. Epigenetic dysregulation of SHANK3 in brain tissues from individuals with autism spectrum disorders. Human Mol Genet, 2014, 23: 1563-1578

45 Vazna A, Musova Z, Vlckova M, Novotna D, Dvorakova L, Hrdlicka M, Havlovicova M, Sedlacek Z. FMRl gene expansion, large deletion of $\mathrm{Xp}$, and skewed $\mathrm{X}$-inactivation in a girl with mental retardation and autism. Am J Med Genet A, 2010, 152a: 1273-1277

46 Nguyen A, Rauch TA, Pfeifer GP, Hu VW. Global methylation profiling of lymphoblastoid cell lines reveals epigenetic contributions to autism spectrum disorders and a novel autism candidate gene, RORA, whose protein product is reduced in autistic brain. FASEB J, 2010, 24: 3036-3051

47 Ladd-Acosta C, Hansen KD, Briem E, Fallin MD, Kaufmann WE, Feinberg AP. Common DNA methylation alterations in multiple brain regions in autism. Mol Psychiatry, 2014, 19: 862-871

48 Wong CC, Meaburn EL, Ronald A, Price TS, Jeffries AR, Schalkwyk LC, Plomin R, Mill J. Methylomic analysis of monozygotic twins discordant for autism spectrum disorder and related behavioural traits. Mol Psychiatry, 2014, 19: 495-503

49 Cheung I, Shulha HP, Jiang Y, Matevossian A, Wang J, Weng Z, Akbarian S. Developmental regulation and individual differences of neuronal H3K4me3 epigenomes in the prefrontal cortex. Proc Natl Acad Sci USA, 2010, 107: 8824-8829

50 de la Torre-Ubieta L, Bonni A. Combinatorial assembly of neurons: from chromatin to dendrites. Trends Cell Biol, 2008, 18: 48-51

51 Ronan JL, Wu W, Crabtree GR. From neural development to cognition: unexpected roles for chromatin. Nat Rev Genet, 2013, 14: 347-359

52 Sandner G, Host L, Angst MJ, Guiberteau T, Guignard B, Zwiller J. The HDAC inhibitor phenylbutyrate reverses effects of neonatal ventral hippocampal lesion in rats. Front Psychiatry, 2011, 1: 153

53 Adegbola A, Gao H, Sommer S, Browning M. A novel mutation in JARIDIC/SMCX in a patient with autism spectrum disorder (ASD). Am J Med Genet A, 2008, 146A: 505-511

54 Goncalves TF, Goncalves AP, Fintelman Rodrigues N, Dos Santos JM, Pimentel MM, Santos-Reboucas CB. KDM5C mutational screening among males with intellectual disability suggestive of $\mathrm{X}$-Linked inheritance and review of the literature. Eur J Med Genet, 2014, 57: 138-144

55 Halgren C, Kjaergaard S, Bak M, Hansen C, El-Schich Z, Anderson CM, Henriksen KF,Hjalgrim H,Kirchhoff M,Bijlsma EK,Nielsen M,den Hollander NS,Ruivenkamp CA,Isidor B,Le Caignec C,Zannolli R,Mucciolo M,Renieri A,Mari F,Anderlid BM,Andrieux J,Dieux A,Tommerup N, Bache I. Corpus callosum abnormalities, intellectual disability, speech impairment, and autism in patients with haploinsufficiency of ARID1B. Clin Genet, 2012, 82: 248-255

56 Neale BM, Kou Y, Liu L, Ma'ayan A, Samocha KE, Sabo A, Lin CF, Stevens C, Wang LS, Makarov V, Polak P, Yoon S, Maguire J, Crawford EL, Campbell NG, Geller ET, Valladares O, Schafer C, Liu H, Zhao T, Cai G, Lihm J, Dannenfelser R, Jabado O, Peralta Z, Nagaswamy U, Muzny D, Reid JG, Newsham I, Wu Y, Lewis L, Han Y, Voight BF, Lim E, Rossin E, Kirby A, Flannick J, Fromer M, Shakir K, Fennell T, Garimella K, Banks E, Poplin R, Gabriel S, DePristo M, Wimbish JR, Boone BE, Levy SE, Betancur C, Sunyaev S, Boerwinkle E, Buxbaum JD, Cook EH Jr, Devlin B, Gibbs RA, Roeder K, Schellenberg GD, Sutcliffe JS, Daly MJ. Patterns and rates of exonic de novo mutations in autism spectrum disorders. Nature, 2012, 485: 242-245

57 Talkowski ME, Rosenfeld JA, Blumenthal I, Pillalamarri V, Chiang C, Heilbut A, Ernst C, Hanscom C, Rossin E, Lindgren AM, Pereira S, Ruderfer D, Kirby A, Ripke S, Harris DJ, Lee JH, Ha K, Kim HG, Solomon BD, Gropman AL, Lucente D, Sims K, Ohsumi TK, Borowsky ML, Loranger S, Quade B, Lage K, Miles J, Wu BL, Shen Y,
Neale B, Shaffer LG, Daly MJ, Morton CC, Gusella JF. Sequencing chromosomal abnormalities reveals neurodevelopmental loci that confer risk across diagnostic boundaries. Cell, 2012, 149: 525-537

58 Jiang YH, Yuen RK, Jin X, Wang M, Chen N, Wu X, Ju J, Mei J, Shi Y, He M, Wang G, Liang J, Wang Z, Cao D, Carter MT, Chrysler C, Drmic IE, Howe JL, Lau L, Marshall CR, Merico D, Nalpathamkalam T, Thiruvahindrapuram B, Thompson A, Uddin M, Walker S, Luo J, Anagnostou E, Zwaigenbaum L, Ring RH, Wang J, Lajonchere C, Wang J, Shih A, Szatmari P, Yang H, Dawson G, Li Y, Scherer SW. Detection of clinically relevant genetic variants in autism spectrum disorder by whole-genome sequencing. Am J Hum Genet, 2013, 93: 249-263

59 Tahiliani M, Mei P, Fang R, Leonor T, Rutenberg M, Shimizu F, Li J, Rao A, Shi Y. The histone $H 3 K 4$ demethylase SMCX links REST target genes to X-linked mental retardation. Nature, 2007, 447: 601-605

60 Ben-David E, Shifman S. Combined analysis of exome sequencing points toward a major role for transcription regulation during brain development in autism. Mol Psychiatry, 2013, 18: 1054-1056

61 Wang KC, Yang YW, Liu B, Sanyal A, Corces-Zimmerman R, Chen Y, Lajoie BR, Protacio A, Flynn RA,Gupta RA,Wysocka J, Lei M, Dekker J, Helms JA, Chang HY. A long noncoding RNA maintains active chromatin to coordinate homeotic gene expression. Nature, 2011, 472: 120-124

62 Magistri M, Faghihi MA, St Laurent G, 3rd, Wahlestedt C. Regulation of chromatin structure by long noncoding RNAs: focus on natural antisense transcripts. Trends Genet, 2012, 28: 389-396

63 Ziats MN, Rennert OM. Aberrant expression of long noncoding RNAs in autistic brain. J Mol Neurosci, 2013, 49: 589-593

64 Boulanger LM. Immune proteins in brain development and synaptic plasticity. Neuron, 2009, 64: 93-109

65 Huh GS, Boulanger LM, Du H, Riquelme PA, Brotz TM, Shatz CJ. Functional requirement for class I MHC in CNS development and plasticity. Science, 2000, 290: 2155-2159

66 Glynn MW, Elmer BM, Garay PA, Liu XB, Needleman LA, El-Sabeawy F, McAllister AK. MHCI negatively regulates synapse density during the establishment of cortical connections. Nat Neurosci, 2011, 14: 442-451

67 Elmer BM, Estes ML, Barrow SL, McAllister AK. MHCI requires MEF2 transcription factors to negatively regulate synapse density during development and in disease. J Neurosci, 2013, 33: 13791-13804

68 Stevens B, Allen NJ, Vazquez LE, Howell GR, Christopherson KS, Nouri N, Micheva KD, Mehalow AK, Huberman AD, Stafford B, Sher A, Litke AM, Lambris JD, Smith SJ, John SW, Barres BA. The classical complement cascade mediates CNS synapse elimination. Cell, 2007, 131: 1164-1178

69 Kaneko M, Stellwagen D, Malenka RC, Stryker MP. Tumor necrosis factor-alpha mediates one component of competitive, experiencedependent plasticity in developing visual cortex. Neuron, 2008, 58: 673-680

70 Onore C, Careaga M, Ashwood P. The role of immune dysfunction in the pathophysiology of autism. Brain Behav Immun, 2012, 26: 383-392

71 Croen LA, Braunschweig D, Haapanen L, Yoshida CK, Fireman B, Grether JK, Kharrazi M, Hansen RL, Ashwood P, Van de Water J. Maternal mid-pregnancy autoantibodies to fetal brain protein: the early markers for autism study. Biol Psychiatry, 2008, 64: 583-588

72 Patterson PH. Immune involvement in schizophrenia and autism: etiology, pathology and animal models. Behav Brain Res, 2009, 204: 313-321

73 Diamond B, Huerta PT, Mina-Osorio P, Kowal C, Volpe BT. Losing your nerves? Maybe it's the antibodies. Nat Rev Immunol, 2009, 9: 449-456

74 Braunschweig D, Ashwood P, Krakowiak P, Hertz-Picciotto I, Hansen R, Croen LA, Pessah IN, Van de Water J. Autism: maternally derived antibodies specific for fetal brain proteins. Neurotoxicology, 2008, 29: 226-231

75 Bauman MD, Iosif AM, Ashwood P, Braunschweig D, Lee A, 
Schumann CM, Van de Water J, Amaral DG. Maternal antibodies from mothers of children with autism alter brain growth and social behavior development in the rhesus monkey. Transl Psychiatry, 2013, 3: e278

76 Li X, Chauhan A, Sheikh AM, Patil S, Chauhan V, Li XM, Brown T, Malik M. Elevated immune response in the brain of autistic patients. J Neuroimmunol, 2009, 207: 111-116

77 Morgan JT, Chana G, Pardo CA, Achim C, Semendeferi K, Buckwalter J, Courchesne E, Everall IP. Microglial activation and increased microglial density observed in the dorsolateral prefrontal cortex in autism. Biol Psychiatry, 2010, 68: 368-376

78 Tambuyzer BR, Ponsaerts P, Nouwen EJ. Microglia: gatekeepers of central nervous system immunology. J Leukoc Biol, 2009, 85: $352-370$

79 Tremblay ME, Stevens B, Sierra A, Wake H, Bessis A, Nimmerjahn A. The role of microglia in the healthy brain. J Neurosci, 2011, 31: 16064-16069

80 Suzuki K, Sugihara G, Ouchi Y, Nakamura K, Futatsubashi M, Takebayashi K, Yoshihara Y, Omata K, Matsumoto K, Tsuchiya KJ, Iwata Y, Tsujii M, Sugiyama T, Mori N. Microglial activation in young adults with autism spectrum disorder. JAMA Psychiatry, 2013, 70: 49-58

81 Ehninger D, Sano Y, de Vries PJ, Dies K, Franz D, Geschwind DH, Kaur M,Lee YS,Li W,Lowe JK,Nakagawa JA,Sahin M,Smith K,Whittemore V,Silva AJ. Gestational immune activation and Tsc2 haploinsufficiency cooperate to disrupt fetal survival and may perturb social behavior in adult mice. Mol Psychiatry, 2012, 17: 62-70

82 de Theije CG, Wopereis H, Ramadan M, van Eijndthoven T, Lambert J, Knol J, Garssen J, Kraneveld AD, Oozeer R. Altered gut microbiota and activity in a murine model of autism spectrum disorders. Brain Behav Immun, 2014, 37: 197-206

83 Coury DL, Ashwood P, Fasano A, Fuchs G, Geraghty M, Kaul A, Mawe G, Patterson P, Jones NE. Gastrointestinal conditions in children with autism spectrum disorder: developing a research agenda. Pediatrics, 2012, 130 Suppl 2: S160-S168

84 Chaidez V, Hansen RL, Hertz-Picciotto I. Gastrointestinal problems in children with autism, developmental delays or typical development. J Autism Dev Disord, 2014, 44: 1117-1127

85 Williams BL, Hornig M, Buie T, Bauman ML, Cho Paik M, Wick I, Bennett A, Jabado O, Hirschberg DL, Lipkin WI. Impaired carbohydrate digestion and transport and mucosal dysbiosis in the intestines of children with autism and gastrointestinal disturbances. PLoS One, 2011, 6: e24585

86 Walker SJ, Fortunato J, Gonzalez LG, Krigsman A. Identification of unique gene expression profile in children with regressive autism spectrum disorder (ASD) and ileocolitis. PLoS One, 2013, 8: e58058

87 Wang Y, Kasper LH. The role of microbiome in central nervous system disorders. Brain Behav Immun, 2014, 38C: 1-12

88 Cryan JF, Dinan TG. Mind-altering microorganisms: the impact of the gut microbiota on brain and behaviour. Nat Rev Neurosci, 2012, 13: 701-712

89 Desbonnet L, Clarke G, Shanahan F, Dinan TG, Cryan JF. Microbiota is essential for social development in the mouse. Mol Psychiatry, 2014, 19: 146-148

90 Hsiao EY, McBride SW, Hsien S, Sharon G, Hyde ER, McCue T, Codelli JA, Chow J, Reisman SE, Petrosino JF, Patterson PH, Mazmanian SK. Microbiota modulate behavioral and physiological abnormalities associated with neurodevelopmental disorders. Cell, 2013, 155: 1451-1463

Open Access This article is distributed under the terms of the Creative Commons Attribution License which permits any use, distribution, and reproduction in any medium, provided the original author(s) and source are credited.

\section{Supporting Information}

Appendix: Gene resource and databases for ASD

The supporting information is available online at life.scichina.com and link.springer.com. The supporting materials are published as submitted, without typesetting or editing. The responsibility for scientific accuracy and content remains entirely with the authors. 